\title{
Veterans' Experiences of Successfully Managing Post-Traumatic Stress Disorder
}

Parry. G., Barrett, A. and Hodge, S. (2021) Veterans' Experiences of Successfully Managing Post-Traumatic Stress Disorder. Mental Health Review Journal.

\section{Authors}

Dr Gemma Parry (1)

Dr Suzanne Hodge (1)

Dr Alan Barrett (2)

\section{Institutional affiliations}

(1) Clinical Psychology Doctoral Programme, Division of Health Research, Lancaster University, Lancaster, UK

(2) Military Veterans' Service, Pennine Care NHS Foundation Trust, UK

\section{Contact details}

Dr Gemma Parry

Clinical Psychologist

gemma.parry7@nhs.net

Dr Suzanne Hodge

Lecturer in Health Research, Doctorate in Clinical Psychology, Division of Health Research, Lancaster University, Lancaster, UK

s.hodge@lancaster.ac.uk

Dr Alan Barrett

Consultant Clinical Psychologist and Clinical Lead, Military Veterans' Service, Pennine Care NHS Foundation Trust, UK

alanbarrett@nhs.net 


\begin{abstract}
Purpose

Prevalence of post-traumatic stress disorder (PTSD) amongst UK veterans is higher than in the general population. However, prevalence figures do not reflect the complexity of this phenomenon and ways in which it may be bound up with veterans' experiences of adjusting to civilian life. The purpose of this study was to explore veterans' experiences of successfully managing PTSD.
\end{abstract}

\title{
Design/methodology/approach
}

Semi-structured interviews were conducted with six veterans who had served in the UK armed forces, and analysed using interpretative phenomenological analysis.

\section{Findings}

Three themes were developed: (1) accepting the problem, taking responsibility and gaining control; (2) talking to the right people; and (3) strategies, antidotes and circling back around. Managing PTSD appeared to be bound up with veterans' experience of renegotiating their identity, where positive aspects of identity lost on leaving the military were rebuilt, and problematic aspects were challenged. Participants sought to speak about their difficulties with others who understood the military context. They felt that their experiences made them a valuable resource to others, and they connected this with a positive sense of identity and value.

\section{Practical implications}

The findings suggest the importance of wider provision of peer support, and education for civilian health services on veterans' needs.

\section{Originality/value}

This study adds to our understanding of what meaningful recovery from PTSD may involve for veterans, in particular its potential interconnectedness with the process of adjusting to civilian life.

\section{Keywords}

Veterans; military; post-traumatic stress; PTSD; qualitative; interpretative phenomenological analysis; IPA 
Overall prevalence of Post-Traumatic Stress Disorder (PTSD) in military personnel is difficult to estimate as data are not collected in a standardised way. However, Stevelink et al. (2018) conducted a phased military cohort study from 2006 to 2016 tracking impact of Operations Enduring Freedom and Iraqi Freedom on mental health of personnel. They found that prevalence of a 'probable PTSD diagnosis' rose from $4 \%$ to $6 \%$ during this period. The estimated prevalence of PTSD in the general UK population is 3\% (McManus et al., 2009).

The consequences of PTSD in veterans can be profound. Firstly veterans reporting trauma appear to experience more difficult transitions from military to civilian life (Morin, 2011). Contributing to this may be other health problems commonly reported alongside PTSD, such as depression and alcohol misuse (Kaysen et al., 2014; Stander et al., 2014), and physical health symptoms (Baker et al., 2009). Together these factors may impact on daily functioning and ability to retain employment, leading to loss of identity, purpose and independence. In addition, relationship difficulties are common with PTSD, perhaps due to emotional numbing, withdrawal, anger and coping through avoidant means, such as alcohol misuse (Ray and Vanstone, 2009). Karney et al. (2008) theorised that the immediate consequences of PTSD described above may lead to a 'cascade' of further negative long-term outcomes including family breakdown, homelessness, violence, entering the criminal justice system, social exclusion and suicide.

Military training aims to socialize recruits into "an idealised culture of warrior masculinity" (Shields, 2016, p.64) where collective identity and social status are based on traditionally masculine traits, like remaining strong and stoic through extreme adversity (Hockey, 2003). Indeed, there is a long history of stigma around military trauma, previously depicted as indicating weakness or cowardice (Shields, 2016). Military masculinity may remain embedded post-discharge, with veterans reporting emotional difficulties as shameful, and a challenge to their identity, strength and power (Cornish et al., 2014). These factors may decrease the likelihood that veterans will seek help to manage PTSD (Shields, 2016). Veterans also report significant barriers to accessing help through civilian mental health services, including stigma and low perceived understanding of military culture (Bunnell et al., 2017). In response to these difficulties, research has focused on barriers to help-seeking (Murphy et al., 2014). However, less is known about how veterans learn to manage PTSD.

Recovery in mental health may be best understood as a process rather than an outcome (Roberts, 2008), requiring a focus on the psychosocial and environmental factors that affect wellbeing, in addition to resolving symptoms (Craig, 2008). However, recovery from PTSD seems to be conceptualised primarily in terms of decreased scores on measures of 
symptoms of PTSD (Giebel et al., 2014). Reducing veterans' complex experiences to numerical outcomes may risk creating disconnection between veterans and service providers, and failing to address veterans' mental health needs.

Within the small existing qualitative literature asking what helps veterans manage PTSD, a study of Portuguese veterans (Ferrajão and Oliveira, 2014) suggested the importance of increased self-awareness, building coping strategies and using social support. In contrast, feeling betrayed by the military, judged by society and depleted in personal resources could be barriers to recovery. Focusing on the experiences of UK veterans treated for PTSD who reported post-traumatic growth (PTG), Palmer et al. (2017) found that experiences of growth were linked to having a catalysing crisis, proactively committing to change, being open to help-seeking, connecting with others with shared experience, understanding reactions to trauma and having a well-informed support network. Although PTG has been connected with reduced symptoms of PTSD (Zoellner and Maercker, 2006), it remains unclear whether this is necessary for veterans to successfully manage PTSD or if it is just one route that recovery might take. Further qualitative enquiry into managing PTSD may therefore be beneficial to build a more complete understanding of this complex phenomenon. Thus the current study aimed to develop a detailed understanding of how veterans successfully manage PTSD.

\section{Method}

\section{Design}

Interpretative Phenomenological Analysis (IPA) was the chosen method, as it allows researchers to gain an insider's perspective into how a person from a unique group makes sense of their experiences (Conrad, 1987). This requires a "double hermeneutic" (Smith and Osborn, 2003, p.51), where researchers make sense of the sense made by participants. IPA allows in-depth case-by-case idiographic exploration of complex phenomena, making it suited to a small sample size (Eatough and Smith, 2008).

\section{Participants}

Purposive sampling was used to recruit veterans with experience of managing PTSD, via veterans' community organisations in North-West England. Individuals could participate if they: were veterans from any branch of the military, with any job role; identified themselves as experiencing PTSD; and had experience of managing these such that they could report what had been helpful. 
Individuals who expressed an interest in participating were given the participant information sheet and time to consider the information before deciding to take part. Participants provided written consent. Six veterans participated, five male, one female, from the British Army ( $n=4)$ and Navy (n=2). Five participants were diagnosed with PTSD, although all reported experiencing symptoms of PTSD. Pseudonyms are used to protect anonymity. Participant demographics can be found in Table 1.

\section{Ethics.}

Lancaster University's Faculty of Health and Medicine Research Ethics Committee reviewed and approved the study.

\section{Data Collection}

Face-to-face semi-structured interviews, focusing on participants' experiences of managing PTSD, were conducted by the first author at community venues. Interviews lasted 65-120 minutes, and were audio recorded and transcribed by the first author.

\section{Data Analysis}

Data analysis was conducted by the first author, in consultation with the second author. The interviews were analysed using IPA as outlined by Smith et al. (2009). This involved reading and re-reading each transcript, and making exploratory notes commenting on participants' descriptions of phenomena, language used and meaning attributed to experiences. These notes were then reduced to key ideas interpreted to be important, resulting in a set of emergent themes for each participant. Emergent themes were then compared across participants for connections, differences, exceptions and broader abstract concepts arising across the data (Table 2). Superordinate themes were developed as a result of this process.

\section{Reflexivity}

In IPA the researcher has an active role in interpreting meaning participants ascribe to phenomena, so the researcher's own views inevitably influence the analysis. The first author was a trainee clinical psychologist working on placement in a veterans' service whilst conducting the study, which may have influenced the interpretations made. To allow views and assumptions to become more conscious a reflective journal was used throughout the project. The first author regularly met with the second author, their research supervisor, to review data collected and interpretations made during analysis. 


\section{Findings}

Three themes were developed: 'accepting the problem, taking responsibility and gaining control'; 'talking to the right people'; and 'strategies, antidotes and circling back around'.

When asked about their experience of PTSD all participants described experiencing symptoms, which included hypervigilance, avoidance, nightmares, flashbacks, anxiety and anger. All were operationally deployed at least once, and experienced unplanned discharge from the military; four due to physical injury or illness, and two as family members insisted that they leave.

\section{Theme 1: Accepting the Problem, Taking Responsibility and Gaining Control}

The first theme integrates participants' reflections on the process of accepting their difficulties with PTSD, from initial denial and lack of awareness, to taking responsibility and gaining control. Life events perceived as 'changing points' in this process altered how participants saw their difficulties and coping mechanisms. The level of control participants felt they had differed, with two participants perceiving less control and reporting taking less responsibility for their actions.

Participants' response to their emotions on discharge was to hide their pain and thus avoid feeling weak - seen as the military way of coping. However, minimising emotions was ineffective at reducing their intensity or impact, and over time they grew more problematic,

Because it took me so long to admit I had a problem, it got deeper and deeper so it was harder and harder to, it took a lot longer, it's taken me years to get to the point of where I am now (Danny).

Not acknowledging the problem or destructive coping mechanisms, such as excessive drinking and self-harm, meant "the abnormal had become normal" (Jackson). Complicating matters was participants' unplanned military discharge, as subsequent lack of closure on their service made it difficult to reintegrate into civilian life,

There was no debrief or de-erm what's the word, of your mind. There was no change or 'right, you're leaving one situation and going into another, and the two are completely different'.... The mind is caught somewhere in between (Stan).

Stan added that the military offered little resettlement, echoing resentment also expressed by others, "Resettlement is the key word here. We never got any. That adds to that chip on the 
shoulder...I came out for the wrong reasons and it's been nothing but a bloody struggle after" (Terry). Loss of military identity and structure led participants to feel depressed, particularly where they had severe physical injuries, "I thought "is this it now?" (Craig).

Participants' narratives indicated a downward spiral of feeling out of control, which continued until it reached what Terry called a "big crescendo", where they could no longer deny their difficulties. Conflicts with loved ones, family breakdown and being unable to work left participants "at rock bottom" (Lauren), with four reporting that they considered suicide. Danny described the meaning this low point had, "it made me realise that I needed to do something about it or I'm just going to be another statistic", a sentiment echoed by Craig, who felt "saved" from suicide. Participants entered mental health services at this point, initially prompted by friends or family members.

Mental health services provided an explanation for participants' experiences that connected them to past events, which helped them reconsider beliefs that their emotional difficulties made them "weak" (Craig) or "effeminate" (Jackson). This made it easier to accept what they were experiencing and take more responsibility for their emotions and actions, to gain a sense of control, "I stopped saying why me, and more like, well for whatever reason I'm going through this, I need to do something about it” (Danny). Some described learning more about PTSD, acknowledging that they could cope with rather than cure it,

I have learned a lot from it, a lot of coping strategies, and now I think I'm in control of my own life. I still have issues and problems, but I will do for the rest of my life. I have accepted that. And I've got a lot of things to look forward to (Terry).

In contrast, Lauren and Stan described not feeling in control, "It's like a never-ending circle. And I feel like that's going to go on for the rest of my life now" (Stan). This related to feeling unable to respond differently in situations that triggered anger, which they justified by externalising responsibility, "we seem to get aggravated because people realise they can trigger us to get angry" (Lauren). This suggested that taking less responsibility for their behaviour related to perceiving less control over PTSD.

\section{Theme 2: Talking to the Right People}

The second theme describes participants' attempts to gain social acceptance and support. All participants saw talking about problems as necessary and helpful, but this was conditional on "talking to the right people" (Terry). 
Participants demonstrated an overwhelming preference for speaking to other veterans about their difficulties, "being able to talk to guys that were similar to me, that was huge" (Stan). They assumed veterans would understand and accept their experiences due to familiarity with the military context, which created a family-like atmosphere where they felt confident speaking without judgement, "I am not the only person having this problem. So if they are able to talk about it, then probably I might as well start talking about it" (Jackson). In contrast to formal relationships with professionals, the informal nature of contact with other veterans made talking easier, "it was a different surrounding. It wasn't questions and answers, we were having a cup of coffee, feet up, chilling out, bit of music, and just started talking about it" (Danny). The consistency of support from the veteran community allowed trust to build over time and for sharing to be comfortably paced. Hearing other veterans' stories helped participants challenge the belief that expressing emotions was weak, and military banter was used as a resource when emotions became too intense.

Some participants preferred seeing ex-military doctors after having negative experiences within civilian healthcare. Danny explained,

...it's not the GPs' fault but then they have not built that understanding.

That's a big problem. It's the same with mental health services. A squaddie would rather have someone from the military to talk to because of the understanding of what it's like to be a soldier.

Participants mostly saw civilian therapists, however they noted a difference in understanding of military context in statutory versus veteran-specific mental health services. When therapists understood the context, participants felt more able to relate to them, which was considered calming and essential for benefitting from therapy. Where therapists had no appreciation of military culture they risked being perceived as insensitive or intrusive. Terry compared his therapists from generic and veteran-specific services to illustrate differing communication styles,

He said 'I've got to ask you, have you got any violent tendencies today' I said 'well no'....So that put me on guard straight away. I never understood that, that it was how we would sort of start off. He kept going on as well about things that I'd witnessed, but do you really want to be reminded? Whereas she, we used to talk about all sorts, but she would very craftily say, although we were talking in general there was questions but I wouldn't realise until afterwards. 
Continuity of support was important where difficulties were complex as once "unbottled" (Terry) participants wanted help managing the strong emotions that resulted, making statutory mental health services limited in what they could offer. Jackson felt that the therapist's personal qualities were also important, "you have to take a psychologist who is patient and understands your needs... who you can trust, and who accepts you as you come today...I believe not every psychologist has got that" (Jackson).

Some participants appreciated "straight-talking" advice from people they could trust, "I'll do it because someone told me to do it" (Craig). This included "talking through what to do differently next time" (Terry) and being strictly instructed to stop harmful and ineffective coping strategies.

The worst experiences communicating their difficulties were with civilians. Some found that stressful interactions with civilians made managing PTSD harder. All participants saw a fundamental divide between themselves and civilians due to their military backgrounds. Frustrations included civilians having "no sense" (Stan), "no logic" (Terry) and "protocols that don't mean anything" (Lauren), implying a struggle to navigate civilian systems that lacked the order and efficiency of the military. Civilians were perceived to focus too much on trivial matters, "there is stuff happening to women out there, there's children being raped, people being murdered, wars going on and you're complaining about a dustbin." (Lauren). They felt civilians generally did not understand or respect their military experience, resulting in them feeling alienated and misunderstood, "they think you shoot somebody everyday" (Terry). Danny and Craig reported less difficulty with civilians and more contact with mixed civilian-veteran groups, through community outreach projects run by veterans' organisations. Danny had talked to school children about his experiences and reported being comfortable answering their direct questions about war. Less judgement was perceived in their childish curiosity than in strong opinions on the morality of war Danny encountered in adults.

Frustrations extended to civilian organisations, (e.g. government and local authorities), who some participants did not feel could provide them with adequate practical support. However, one participant praised his local council for having an ex-forces liaison officer who provided face-to-face support and organised activities for veterans. The inconsistency in services across areas led Terry to view the Armed Forces Covenant as a "rubber stamp activity", commenting "you've served your country now let your country serve you. That hasn't applied to me". 


\section{Theme 3: Strategies, Antidotes and Circling Back Around}

This theme represents what helped participants to actively manage PTSD, following personal acceptance and talking to the right people. It describes how participants managed PTSD alongside negotiating new identities for themselves, integrating aspects of their military identity that remained important to them and challenging the more problematic parts, thus opening up new ways of expressing and managing emotions. Most participants described 'circling back around' to the veteran community, where they further rebuilt identity through renewed belonging and helping other veterans. Efforts to manage PTSD had a positive impact, which to them meant symptoms happened less often, for a shorter duration and were less intense.

Participants recognised they could not always predict when symptoms would be triggered, but they could draw from their military strengths to be prepared with strategies that worked for them, "because in the forces you know what you're doing all the time" (Stan). Managing PTSD was a long-term process that took time and perseverance,

It is not a one-day fix but a process. I will say it was very difficult because it was like I was being taught, like a baby to speak again... you have to train your mind, so it took a long time (Jackson).

Participants adopted a structured routine to establish stability, and some used meticulous record-keeping to mitigate memory difficulties associated with PTSD, allowing them to "shift the burden to the system" (Jackson). Participants adjusted their expectations of themselves to avoid extra stress, for instance by working part-time rather than full-time.

Coping strategies were mainly discovered through mental health services, and focused on mindful activities that would calm them and bring them out of negative thoughts,

My gardening, because you're not deliberately thinking something. That's

why I like to get stuck into my gardening...I just stop and smell this leaf or the disinfectant and think, 'you're gardening'... (Lauren).

Lauren's use of her senses and self-talk were strategies other participants mentioned, as ways to ground and calm themselves during times of extreme emotion. Some used smells they associated with positive emotions that could 'momentarily' take them out of their thoughts and change their mood, "it takes me straight to when I was 8 years old, on the playground" (Lauren). This was helpful for managing flashbacks, nightmares and dissociation, helping Danny "get through the horrible bits" during trauma therapy. 
In addition to methods of calming emotions in situ, time out was used to gain distance from some situations, e.g. interpersonal conflicts. For some the 'antisocial' nature of leaving without explanation caused conflict, but was considered necessary, "It's a very selfish thing to do...but you don't think straight. It is what I needed, I took myself out of the situation" (Stan).

As well as developing concrete strategies for managing PTSD, participants reported developing an ability to see positives in the world around them which balanced negative experiences. This involved being open to creative approaches to expressing emotions,

I was never up for it, I was a combat veteran, not a bloody artist [laughs], but I was encouraged to go. And art to me is better than any medication. In fact since I started doing it I've come off a lot of medication...I learned that the more I did it, the less mentally I was suffering (Danny).

A factor in being open to new methods of expressing emotions was encouragement from others that they respected. Stan explained how he returned to the Falklands and discovered the national flower there whilst painting the landscape, which became symbolic as an 'antidote' for him,

I can still smell that horrible smell from 82 but it was a big antidote, shall we say, for it...And it had a big impact on me. I met a royal marine who was a musician, and he had written a song about his own experiences. And he was taken with the effect this flower had had on me and he said you need to write a song about it. And I laughed at him and said I haven't got a musical bone in my body. He said just do it, write it. So I did.

Other participants described integrating creative solutions into therapy, for instance Danny painted a dominant character to focus on when overwhelmed by thoughts and imagined dialogue with the subject of his nightmares, both of which reduced his symptoms.

All participants described reaching a point where they "circled back around" (Terry) to a positive military identity through engaging with veteran community organisations, in which two participants gained employment and two gained voluntary roles. Involvement in these groups gave an enduring sense of belonging comparable to their military days and supporting other veterans rewarded them with a sense of usefulness within the community,

I'm getting to that point now. It seems to have gone in a massive circle....getting back within the community, helping with my mates here. I've got a new bunch of lads, and this place is a family, it is a family. 
Before I came here I hadn't laughed for months, and I have got this place $110 \%$ to thank for where I am now (Craig).

Participants found it "incredible" (Danny) and "a joy" (Jackson) to be able to pass on what they had learned about managing PTSD through supporting others, giving them a sense of purpose and pride that they found healing,

Now guys come to me, because of what I've gone through...they always

feel confident talking to someone who's in the same boat, somebody that's been there and done it perhaps. But for me that's therapeutic, for me (Danny).

Paid and voluntary work was further associated with self-worth as roles involved being trusted with responsibilities, making participants feel respected and valued.

A final element of renewing lost identity for three participants was re-engaging in activities they stopped when they were injured. Sport had previously been an important part of their identity and a resource for managing stress. By adjusting their expectations and how they practised sport, participants found meaning in returning to an active, competitive environment.

\section{Discussion}

These findings provide detailed understanding of what helped a small sample of veterans to successfully manage PTSD, as part of a difficult, unplanned transition from military to civilian life in which their identity needed to be renegotiated. Participants reported rebuilding the positive parts of identity lost on leaving the military, and challenging the more problematic parts that remained so they could accept PTSD as a problem, talk about it and learn to manage it.

Participants' initial denial of their problems and avoidance of responsibility indicates an external locus of control, where events outside the self are seen to have control over a person's life (Rotter, 1990), which Smith et al. (2018) have linked to avoidance elements of PTSD. Participants' low points seemed to prompt a more internal locus of control where they could take responsibility for learning better ways of coping. These findings support Palmer et al. (2017), who conceptualised the low point as a 'catalysing crisis' that instigated PTG. The idea of 'hitting rock bottom' is also recognised as a catalyst for change in problematic alcohol use, through forcing confrontation with the extent and consequences of the problem (Kirouac et al., 2015). Research has connected an internal locus of control with reduced PTSD 
symptoms (Karstoft et al., 2015). It would be interesting to explore whether this can be cultivated within an early intervention, to avoid veterans having to reach this low point before change seems available to them.

The second theme highlights the importance of talking to others who understand veterans' difficulties in managing PTSD. Participants found some civilians too direct and insensitive, leading them to feel excluded from civilian mental health services and their wider civilian community. This supports Sayer et al.'s (2009) findings which suggest that invalidating socio-cultural environments following trauma create a barrier to talking about experiences. Validating societal responses to self-disclosure of experiences and emotions also seem to be an important factor in PTG (Calhoun, Cann and Tedeschi, 2010).

Within the third theme participants described developing pre-planned strategies for managing their symptoms. In addition, some described the benefits of being open to alternative ways of managing emotions. These findings support existing evidence that masculine socialisation within the military is associated with difficulty explicitly addressing and managing emotions (Lorber and Garcia, 2010). Lauren's views on the military way of coping were similar to male participants', suggesting that military masculinity is not an experience limited to male veterans. The current study suggests that challenging traditionally masculine ways of expressing emotions may open up more helpful ways of managing emotions. Within this theme participants also used the understanding of their difficulties they had gained to help other veterans by taking peer supporting roles within veterans' organisations. Most felt that their experiences made them a valuable resource to others, giving a positive sense of identity around purpose, worth and belonging. The theme suggests that both concrete strategies for managing symptoms, and identity renegotiation related to a broader sense of meaning from experiencing PTSD were salient in order to manage PTSD effectively.

\section{Clinical Implications}

This study underscores the importance of peer support in helping veterans manage PTSD. It may be beneficial for health services to identify veterans experiencing problems as early as possible and encourage community veteran organisation input. This was a vital resource for participants in the study, however they all came across these services after reaching a low point. Prompter referral by GPs and mental health professionals may be needed, but this may require increased awareness of difficulties related to military service and of the resources provided by community veterans' organisations. Better links between NHS 
services and local community organisations could be formed through direct contact, and details of organisations could be included on the NHS veterans' mental health webpage.

Considering the substantial comfort and validation participants gained from other veterans, group interventions may provide an effective way for military-specific services to engage those in early stages of input. Current findings suggest this setting could be a catalyst for veterans to start talking about their problems. Group interventions could also provide psychoeducation to help veterans replace ineffective coping methods with ones that are harmless and effective. Informative therapeutic groups have previously been demonstrated to reduce symptoms of PTSD (Swanson et al., 2009). Holding groups in informal settings, perhaps run by veterans themselves, may help veterans feel more comfortable opening up. There is also evidence that motivational enhancement therapy can be effective for challenging traditionally masculine responses to emotions (Lorber and Garcia, 2010), so using this intervention in a group setting may help veterans to identify and challenge problematic aspects of their identity that make PTSD more difficult to manage.

\section{Limitations}

We aimed to recruit a minimum of six participants. Once six interviews were completed and transcribed the richness of data was assessed as high. The sample was judged to be homogenous (a requirement of IPA) in the similarity of participants' experience of PTSD, such that it was clear that themes emerging from the data were broadly similar. Recruitment was therefore stopped at six. However the modest sample size means that only tentative conclusions can be drawn from the analysis.

As we were using IPA, an in-depth method that requires small samples, we were not aiming for a sample which was representative of all veterans. Nonetheless, it is important to acknowledge that with such a small sample, the range of groups and experiences represented must be limited. Of note, participants recruited were all veterans from the Army and Navy, none from the Royal Air Force. The data gained cannot be assumed to be applicable outside of these groups. It is positive that the sample included one female veteran and two from a minority ethnic group, however such small numbers mean that the variations of experience across those sub-groups could not be explored in any depth. In particular, more female views on the impact of military masculinity on managing emotions may have allowed more detailed exploration of this topic.

Recruitment for the study was through organisations which offer support to veterans. This may have biased results, in particular the third theme, as those within these organisations 
may be more likely to find a veteran community in which they can give and receive peer support valuable. Some veterans who have had negative experiences within the military, for example bullying or military sexual trauma, may be less likely to join such an organisation, and therefore they may have alternate views which are not covered by this study.

\section{Conclusion}

Successful management of PTSD in this study appeared to be intertwined with renegotiating identity as a veteran. Participants reported challenging problematic elements of their identity to open themselves up to new ways of seeing emotions and coping. Talking to other veterans and professionals with understanding of military context reportedly helped participants gain social acceptance. Being part of a veteran community, with experience that could help others felt therapeutic and was seen to strengthen positive parts of a renegotiated identity. Implications include encouraging wider referral to community veteran organisations by healthcare providers and exploring the idea of increased use of veteran peer support groups within health services. 


\section{References}

Baker, D., Heppner, P., Afari, N., Nunnink, S., Kilmer, M., Simmons, Harder, L. and Bosse, B. (2009), "Trauma exposure, branch of service, and physical injury in relation to mental health among US veterans returning from Iraq and Afghanistan”, Military Medicine, Vol. 174 No. 8, pp. 733-778. DOI: 10.7205/MILMED-D-03-3808

Bunnell, B.E., Davidson, T.M., Hamblen, J.L., Cook, D.L., Grubaugh, A.L., Lozano, B.E., Tuerk, P.W. and Ruggiero, K.J., 2017 (2017), "Protocol for the evaluation of a digital storytelling approach to address stigma and improve readiness to seek services among veterans”, Pilot Feasibility Studies, Vol. 3 No. 1, p. 7, DOI: 10.1186/s40814-0170121-3.

Calhoun, L. G., Cann, A. and Tedeschi, R. G. (2010), “The posttraumatic growth model: Sociocultural considerations", in Weiss, T. and Berger, R. (Eds.), Posttraumatic Growth and Culturally Competent Practice: Lessons Learned from Around the Globe, pp. 1-14, John Wiley and Sons Inc., Hoboken, NJ, DOI: 10.1002/9781118270028.ch1

Conrad, P. (1987), "The experience of illness: Recent and new directions", Research in the Sociology of Health Care, Vol. 6 No. 1, p. 31. Retrieved from https://ci.nii.ac.jp/naid/10010859387/

Cornish, M., Thys, A., Vogel, D. and Wade, N. (2014), "Post-deployment difficulties and help seeking barriers among military veterans: Insights and intervention strategies", Professional Psychology: Research and Practice, Vol. 45 No. 6, pp. 405-409. DOI: $10.1037 / \mathrm{a} 0037986$

Craig, T. (2008), "Recovery: Say what you mean and mean what you say", Journal of Mental Health, Vol. 17 No. 2, pp. 125-128. DOI: 10.1080/09638230802003800

Demers, A. (2013), "From death to life: Female veterans, identity negotiation, and reintegration into society”, Journal of Humanistic Psychology, Vol. 53 No. 4, pp. 489515. DOI: $\underline{10.1177 / 0022167812472395}$

Eatough, V., and Smith, J. (2008), "Interpretative phenomenological analysis", In Willig, C. and Stainton-Rogers, W. (Eds.), The Sage Handbook of Qualitative Research in Psychology, pp. 179-197, Sage, London, UK.

Ferrajão, P., and Oliveira, R. (2014), "Self-awareness of mental states, self-integration of personal schemas, perceived social support, posttraumatic and depression levels, and 
moral injury: A mixed-method study among Portuguese war veterans", Traumatology, Vol. 20 No. 4, p. 277. DOI: 10.1037/trm000006

Giebel, C., Clarkson, P., and Challis, D. (2014), "Demographic and clinical characteristics of UK military veterans attending a psychological therapies service", The Psychiatric Bulletin, Vol. 38 No. 6, pp. 270-275. DOI: 10.1192/pb.bp.113.046474

Hockey, J. (2003), "No more heroes: Masculinity in the infantry”, in Higate, P. (Ed.), Military Masculinities: Identity and the State, pp. 15-25, Praeger, Connecticut, US.

Karney, B., Ramchand, R., Osilla, K., Caldarone, L. and Burns, R. (2008), "Predicting the immediate and long-term consequences of post-traumatic stress disorder, depression, and traumatic brain injury in veterans of Operation Enduring Freedom and Operation Iraqi Freedom”, in Tanielian, T. and Jaycox, L. (Ed.), Invisible Wounds of War: Psychological and Cognitive Injuries, their Consequences, and Services to Assist Recovery, RAND Corporation, California, US.

Karstoft, K., Armour, C., Elklit, A. and Solomon, Z. (2015), "The role of locus of control and coping style in predicting longitudinal PTSD-trajectories after combat exposure", Journal of Anxiety Disorders, Vol. 32, pp. 89-94, DOI: 10.1016/j.janxdis.2015.03.007

Kaysen, D., Schumm, J., Pedersen, E., Seim, R., Bedard-Gilligan, M. and Chard, K. (2014), "Cognitive processing therapy for veterans with comorbid PTSD and alcohol use disorders", Addictive Behaviors, Vol. 39 No. 2, pp. 420-427. DOI: $\underline{10.1016 / j . a d d b e h .2013 .08 .016}$

Kirouac, M., Frohe, T. and Witkiewitz, K. (2015), "Toward the operationalization and examination of "hitting bottom" for problematic alcohol use: A literature review", Alcoholism Treatment Quarterly, Vol. 33 No. 3, pp. 312-327. DOI: $\underline{10.1080 / 07347324.2015 .1050934}$

Lorber, W. and Garcia, H. (2010), "Not supposed to feel this: Traditional masculinity in psychotherapy with male veterans returning from Afghanistan and Iraq", Psychotherapy: Theory, Research, Practice, Training, Vol. 47 No. 3, pp. 296. DOI: $\underline{10.1037 / \mathrm{a} 0021161}$

McManus, S., Meltzer, H., Brugha, T., Bebbington, P. and Jenkins, R. (2009), Adult psychiatric morbidity in England, 2007: Results of a household survey, Retrieved from http://discovery.ucl.ac.uk/164862/

Morin, R. (2011), The difficult transition from military to civilian life, Retrieved from http://www.pewsocialtrends.org/2011/12/08/the-difficulttransition-from-military-tocivilian-life/ 
Murphy, D., Hunt, E., Luzon, O., and Greenberg, N. (2014), "Exploring positive pathways to care for members of the UK Armed Forces receiving treatment for PTSD: A qualitative study”, European Journal of Psycho-traumatology, Vol. 5 No. 1, pp. 1-8. DOI: $10.3402 /$ ejpt.v5.21759

Palmer, E., Murphy, D. and Spencer-Harper, L. (2017), "Experience of post-traumatic growth in UK veterans with PTSD: A qualitative study", Journal of the Royal Army Medical Corps, Vol. 163 No. 3, pp. 171-176. DOI: 10.1136/jramc-2015-000607

Ray, S. and Vanstone, M. (2009), “The impact of PTSD on veterans' family relationships: An interpretative phenomenological inquiry", International Journal of Nursing Studies, Vol. 46 No. 6, pp. 838-847. DOI: 10.1016/j.ijnurstu.2009.01.002

Roberts, M. (2008), "Facilitating recovery by making sense of suffering: A Nietzschean perspective", Journal of Psychiatric and Mental Health Nursing, Vol. 15 No. 9, pp. 743-748. DOI: 10.1111/j.1365-2850.2008.01300.x

Rotter, J. (1990), "Internal versus external control of reinforcement: A case history of a variable", American Psychologist, Vol. 45 No. 4, pp. 489-493. DOI: 10.1037/0003$\underline{066 X .45 .4 .489}$

Sayer, N., Friedemann-Sanchez, G., Spoont, M., Murdoch, M., Parker, L., Chiros, C. and Rosenheck, R. (2009), “A qualitative study of determinants of PTSD treatment initiation in veterans", Psychiatry: Interpersonal and Biological Processes, Vol. 72 No. 3, pp. 238-255. DOI: 10.1521/psyc.2009.72.3.238

Shields, D. (2016), "Military masculinity, movies, and the DSM: Narratives of institutionally (en)gendered trauma", Psychology of Men and Masculinity, Vol. 17 No. 1, pp. 64-73. DOI: $\underline{10.1037 / \mathrm{a} 0039218}$

Smith, J., Flowers, P. and Larkin, M. (2009), Interpretive Phenomenological Analysis: Theory, Method and Research, Sage, London, UK.

Smith, J. and Osborn, M. (2003), "Interpretative phenomenological analysis", in Smith, J. (Ed.), Qualitative Psychology. A Practical Guide to Research Methods, pp. 51-80, Sage, London, UK.

Smith, N.B., Sippel, L.M., Presseau, C., Rozek, D., Mota, N., Gordon, C., Horvath, M. and Harpaz-Rotem, I., (2018), "Locus of control in US combat veterans: Unique associations with posttraumatic stress disorder 5-factor model symptom clusters", Psychiatry Research, Vol. 268, 152-156. DOI:

10.1016/j.psychres.2018.07.015 
Stander, V., Thomsen, C. and Highfill-McRoy, R. (2014), "Etiology of depression comorbidity in combat-related PTSD: A review of the literature", Clinical Psychology Review, Vol. 34 No. 2, pp. 87-98. DOI: 10.1016/j.cpr.2013.12.002

Stevelink, S., Jones, M., Hull, L., Pernet, D., MacCrimmon, S., Goodwin, L., . . Wessely, S. (2018)._Mental health outcomes at the end of the British involvement in the Iraq and Afghanistan conflicts: a cohort study. British Journal of Psychiatry, 0, 1-8. DOI: 10.1192/bjp.2018.1175

Swanson, L., Favorite, T., Horin, E. and Arnedt, J. (2009), “A combined group treatment for nightmares and insomnia in combat veterans: A pilot study", Journal of Traumatic Stress: Official Publication of the International Society for Traumatic Stress Studies, Vol. 22 No. 6, pp. 639-642. DOI: $\underline{10.1002 / j t s .20468}$

Zoellner, T. and Maercker, A. (2006), "Posttraumatic growth in clinical psychology: A critical review and introduction of a two component model", Clinical Psychology Review, Vol. 26 No. 5, pp. 626-653. DOI: 10.1016/j.cpr.2006.01.008 
Table 1: Participant demographic details

\begin{tabular}{|c|c|c|c|c|c|c|}
\hline Participant & Age & Military branch & Role & Years served & Employed & $\begin{array}{l}\text { Diagnosis/ } \\
\text { Diagnoses }\end{array}$ \\
\hline Danny & 58 & Army & Gunner & $\begin{array}{l}1976-1983 \\
\text { (8 years) }\end{array}$ & Volunteer & $\begin{array}{l}\text { PTSD, dissociative } \\
\text { disorder, } \\
\text { personality disorder }\end{array}$ \\
\hline Stan & 58 & Navy & $\begin{array}{l}\text { Catering } \\
\text { accountant }\end{array}$ & $\begin{array}{l}1976-1983 \\
(8 \text { years })\end{array}$ & Part-time & $\begin{array}{l}\text { Adjustment } \\
\text { disorder }\end{array}$ \\
\hline Lauren & 56 & Navy & Medic & $\begin{array}{l}1986-2000 \\
(14 \text { years })\end{array}$ & $\begin{array}{l}\text { Part-time - } \\
\text { Permitted work } \\
\text { scheme }\end{array}$ & PTSD \\
\hline Craig & 44 & Army & Engineer & $\begin{array}{l}1990-2000 \\
(10 \text { years })\end{array}$ & Part-time & PTSD \\
\hline Jackson & 33 & Army & Medic & $\begin{array}{l}2005-2010 \\
(5 \text { years })\end{array}$ & Volunteer & PTSD \\
\hline
\end{tabular}


Table 2: Participant emergent themes related to superordinate themes

\begin{tabular}{|c|c|c|c|c|c|c|}
\hline Participant & Danny & Stan & Terry & Lauren & Craig & Jackson \\
\hline $\begin{array}{l}\text { Theme 1: } \\
\text { Accepting the } \\
\text { problem, } \\
\text { taking } \\
\text { responsibility } \\
\text { and gaining } \\
\text { control }\end{array}$ & $\begin{array}{l}\text { Army way - hide } \\
\text { emotions. } \\
\text { Lost in civvy street. } \\
\text { Became ill fast - slow } \\
\text { to realise. } \\
\text { Problems deepen with } \\
\text { denial. } \\
\text { Not taking } \\
\text { responsibility. } \\
\text { Life in hands of fate / } \\
\text { others. } \\
\text { Actions can no longer } \\
\text { be denied. } \\
\text { Become a statistic or } \\
\text { combat the problem. } \\
\text { Taking responsibility. } \\
\text { Accepting PTSD - no } \\
\text { more excuses. } \\
\text { Making sense of } \\
\text { symptoms. } \\
\text { Gaining control } \\
\text { mitigates shame. } \\
\text { Challenge PTSD as a } \\
\text { weakness. } \\
\text { Finding courage. }\end{array}$ & $\begin{array}{l}\text { Stuck in military } \\
\text { mind-set. } \\
\text { Left alone - no } \\
\text { forward brief, no } \\
\text { resettlement. } \\
\text { Stuck in a cycle. } \\
\text { Life in hands of } \\
\text { others. } \\
\text { Low point. } \\
\text { Lightbulb moment. } \\
\text { Actions have } \\
\text { consequences. } \\
\text { Motivation to change. } \\
\text { Still stuck in cycle. }\end{array}$ & $\begin{array}{l}\text { Army rules - shut up } \\
\text { about emotions. } \\
\text { Military tie cut - left } \\
\text { useless. } \\
\text { No resettlement. } \\
\text { Chip on shoulder. } \\
\text { Life in hands of fate. } \\
\text { Came to a crescendo. } \\
\text { Considering the } \\
\text { consequences. } \\
\text { Replugging your own } \\
\text { wires. } \\
\text { Feeling in control. } \\
\text { Using courage to } \\
\text { access help. }\end{array}$ & $\begin{array}{l}\text { Grit teeth and get on } \\
\text { with it. } \\
\text { Not desensitised or } \\
\text { prepared for civvy } \\
\text { street. } \\
\text { Didn't see it starting. } \\
\text { Rock bottom - } \\
\text { considered suicide. } \\
\text { Resolve to find } \\
\text { another way. } \\
\text { Manage it as best I } \\
\text { can. } \\
\text { Fate still in hands of } \\
\text { others. }\end{array}$ & $\begin{array}{l}\text { Army way - suck it } \\
\text { up soldier. } \\
\text { On your own in civvy } \\
\text { street - thanks, bye. } \\
\text { Is this it now? } \\
\text { Being an idiot but } \\
\text { couldn't see it. } \\
\text { Mental breakdown - } \\
\text { saved from suicide. } \\
\text { Changing point. } \\
\text { What am I doing? } \\
\text { Others as inspiration } \\
\text { and clarity. } \\
\text { Others inspire } \\
\text { courage. } \\
\text { Coming out the other } \\
\text { end. } \\
\text { Challenge PTSD as a } \\
\text { weakness. }\end{array}$ & $\begin{array}{l}\text { Army way - soldier } \\
\text { on. } \\
\text { Mind in Iraq - body } \\
\text { in UK. } \\
\text { Loss of physical } \\
\text { functioning. } \\
\text { Abnormal became } \\
\text { normal. } \\
\text { Breakdown of family } \\
\text { - feeling suicidal. } \\
\text { Motivation to change. } \\
\text { Problem can be } \\
\text { treated not cured. } \\
\text { What have I been } \\
\text { doing? }\end{array}$ \\
\hline
\end{tabular}




\begin{tabular}{|c|c|c|c|c|c|c|}
\hline Participant & Danny & Stan & Terry & Lauren & Craig & Jackson \\
\hline $\begin{array}{l}\text { Theme 2: } \\
\text { Talking to the } \\
\text { right people }\end{array}$ & $\begin{array}{l}\text { Painful but necessary. } \\
\text { Long haul support - } \\
\text { one thing at a time. } \\
\text { Not under the } \\
\text { spotlight. } \\
\text { Other veterans in } \\
\text { same boat. } \\
\text { Tell me what to do } \\
\text { and I'll do it. } \\
\text { Civilians don't have } \\
\text { the understanding. }\end{array}$ & $\begin{array}{l}\text { Calmed through } \\
\text { relating. } \\
\text { Veterans no pressure. } \\
\text { Government on } \\
\text { different page. } \\
\text { Civilians a risk not a } \\
\text { help. } \\
\text { Face to face support. }\end{array}$ & $\begin{array}{l}\text { Talking to the right } \\
\text { people. } \\
\text { Indirect more } \\
\text { comfortable. } \\
\text { Veterans have } \\
\text { unwritten rules - } \\
\text { know without } \\
\text { knowing. } \\
\text { Veterans no pressure. } \\
\text { Civilians judge a } \\
\text { book by its cover. } \\
\text { Served country but } \\
\text { not served me. } \\
\text { Tell me what to do } \\
\text { next time. }\end{array}$ & $\begin{array}{l}\text { Too complex for } \\
\text { treatment. } \\
\text { Doctors don't care. } \\
\text { Services inflexible. } \\
\text { Veterans get it. } \\
\text { Comradery and } \\
\text { banter. } \\
\text { I'm not a civvy. }\end{array}$ & $\begin{array}{l}\text { Talking releases } \\
\text { emotion. } \\
\text { Once open can't close } \\
\text { it. } \\
\text { Understand / accept } \\
\text { military context. } \\
\text { Calm/unrushed vs } \\
\text { interfered with. } \\
\text { Support that won't } \\
\text { leave. } \\
\text { Veterans - no } \\
\text { questions and } \\
\text { answers. } \\
\text { I'll do what I'm told. }\end{array}$ & $\begin{array}{l}\text { If other veterans can } \\
\text { talk I can. } \\
\text { Patience, trust and } \\
\text { understanding. } \\
\text { Accept you as you } \\
\text { come today. } \\
\text { Adjustments make } \\
\text { big difference. } \\
\text { Mistrust civilian } \\
\text { services. }\end{array}$ \\
\hline
\end{tabular}

\begin{tabular}{|c|c|c|c|c|c|c|}
\hline Participant & Danny & Stan & Terry & Lauren & Craig & Jackson \\
\hline $\begin{array}{l}\text { Theme 3: } \\
\text { Strategies, } \\
\text { antidotes and } \\
\text { circling back } \\
\text { around }\end{array}$ & $\begin{array}{l}\text { Time out - selfish but } \\
\text { necessary. } \\
\text { Small things together } \\
\text { have a big impact. } \\
\text { Smells to ground. } \\
\text { Self-talk - gain } \\
\text { control. } \\
\text { Expressing emotions } \\
\text { releases them - it's } \\
\text { not weak. } \\
\text { Open to creative } \\
\text { outlets. }\end{array}$ & $\begin{array}{l}\text { Escape pressure and } \\
\text { burden. } \\
\text { Escape avoids } \\
\text { consequences. } \\
\text { Putting in the hard } \\
\text { work. } \\
\text { Detail the plan. } \\
\text { Antidote - symbol of } \\
\text { what's good. } \\
\text { New ways to express } \\
\text { emotions. }\end{array}$ & $\begin{array}{l}\text { An antisocial illness. } \\
\text { Drawing on past } \\
\text { skills. } \\
\text { Having a plan in } \\
\text { place. } \\
\text { Organise yourself the } \\
\text { military way. } \\
\text { Use the good to } \\
\text { balance the bad. }\end{array}$ & $\begin{array}{l}\text { Managing is keeping } \\
\text { calm. } \\
\text { Escape to avoid } \\
\text { response. } \\
\text { Grounding - from } \\
\text { anger to childhood } \\
\text { memories. } \\
\text { Keep busy but pause } \\
\text { to be present. } \\
\text { Military structure. } \\
\text { Self-talk - keep calm } \\
\text { and release anger. }\end{array}$ & $\begin{array}{l}\text { Take a break - calm } \\
\text { down. } \\
\text { Strategies for } \\
\text { symptoms - a clear } \\
\text { plan. } \\
\text { Grounding and } \\
\text { distracting - get out } \\
\text { of thoughts. } \\
\text { Use voice in head. } \\
\text { Fingers are black not } \\
\text { green. }\end{array}$ & $\begin{array}{l}\text { Process not a one day } \\
\text { fix. Hard work. } \\
\text { Take a break, change } \\
\text { the response. } \\
\text { Momentary mood } \\
\text { change. } \\
\text { If it works double it. } \\
\text { Symbols of calm. } \\
\text { Shift the burden of } \\
\text { worries. } \\
\text { Self-talk reassuring. }\end{array}$ \\
\hline
\end{tabular}




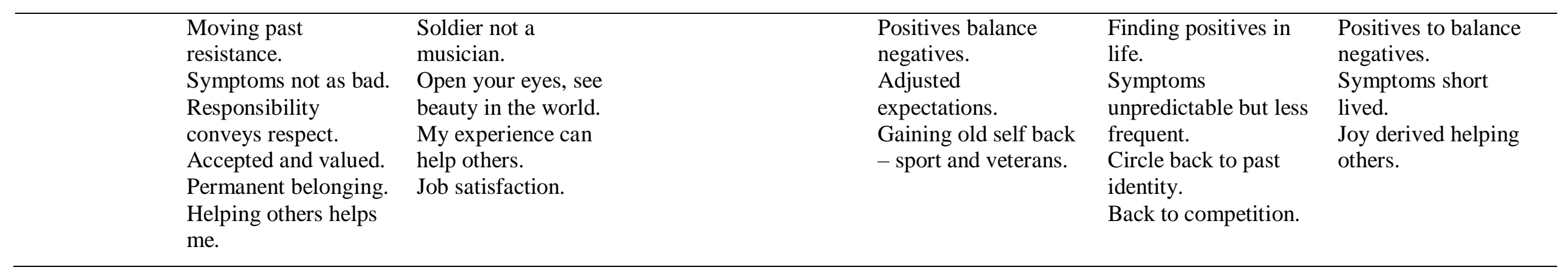

